\title{
AUGMENTED REALITY, SEBUAH TREN DAN NILAI DALAM PERKEMBANGAN INDUSTRI PARIWISATA
}

\author{
I Putu Sagita Jaya Utama \\ Politeknik Negeri Bali \\ sagitawindha@gmail.com \\ I Made Arsa Wiguna \\ Institut Hindu Dharma Negeri Denpasar \\ imadearsawiguna@gmail.com
}

\begin{abstract}
The use of modern technology is a necessity for many destinations to remain competitive and attractive to modern tourists. A form of new technology that is increasingly being used in public spaces is virtual reality and augmented reality (AR). How AR plays a role in the development of the tourism industry, so that it becomes a trend and value, is a reality that explored with a qualitative approach and a review of some relevant literature. The results of the study found that Augmented Reality is very instrumental in projecting additional information about attractions, accessibility and amenities in the tourism environment to be closer to everyone.
\end{abstract}

Keywords: Augmented Reality, Tourism.

\begin{abstract}
Abstrak
Penggunaan teknologi modern menjadi kebutuhan banyak destinasi untuk tetap kompetitif dan menarik bagi wisatawan modern. Suatu bentuk teknologi baru yang semakin banyak digunakan di ruang publik adalah realitas virtual dan augmented reality (AR). Bagaimana AR berperan dalam perkembangan industry pariwisata, sehingga menjadi trend dan bernilai, merupakan suatu kenyataan yang digali lewat tulisan ini melalui pendekatan kualitatif serta review atas beberapa literature yang relevan. Hasil dari penelitian menemukan bahwa Augmented Reality sangat berperan untuk memproyeksikan informasi tambahan tentang atraksi, aksesibility dan amenity dalam lingkungan pariwisata menjadi lebih dekat bagi semua orang.
\end{abstract}

Kata kunci: Augmented Reality, Pariwisata.

\section{A. LATAR BELAKANG}

Berbicara tentang Augmented Reality (AR) secara otomatis kita akan membayangkan teknologi modern dari berbagai media terutama media sosial yang sangat booming dewasa ini. Dibuat dengan kombinasi beberapa objek nyata dan virtual dalam bentuk aplikasi digital yang terpasang pada perangkat komputer, phone cell, tablet maupun gadget lainnya, membuatnya begitu mudah untuk diakses semua orang. Pada era tahun 2000-an kita pasti masih terbayang dalam ingatan bagaimana PC (personal computer) yang secara signifikan telah mengubah perilaku kebanyakan orang sebagai konsumen dalam penggunaan komputer. Sebagai solusi atas permasalahan kebutuhan perangkat yang lebih ringkas, portable dan mobile oriented. Adam Osborne, seorang pria berkewarganegaraan Amerika keturunan Inggris, merintis perkembangan laptop yang mengambil alih peran PC bagi sebagian besar orang. Berkat pola kebutuhan yang sama, kembali terulang dengan cepat kehadiran perangkat telepon selular seperti smartphone dengan menu media sosialnya hingga saat ini. Dengan menjadi inti dari strategi pemasaran digital, saluran media sosial kemudian mencari tahu lalu menerapkan taktik terbaik untuk mempromosikan aneka produk serta layanan dan menerapkan cara-cara baru dalam memberikan pengalaman interaktif. Dalam bisnis retail contohnya, bagaimana EBay sudah lebih dulu memperkenalkan 
platform ecommerce virtual di Australia. Para konsumen dipermudah dengan fitur yang lebih detail mampu memeriksa produk sebelum transaksi terjadi, kemudian menyelesaikan pembayaran, lalu menunggu kurir ekspedisi untuk datang membawa barang pesanan bahkan hingga sampai di depan pintu rumah mereka. Dalam dunia edukasi, sebagai contoh aplikasi aplikasi StarWalk yang mampu menjawab tantangan di dunia pendidikan sekolah yang memudahkan para siswa ataupun masyarakat umum melihat dan mempelajari sistem tata surya, yang kemudian membantu siswa memahami pelajaran lebih baik. Untuk menarik pelanggan baru dan potensial, para penyedia layanan AR berupaya menarik perhatian konsumen dan membuat penawaran yang tidak bisa ditolak oleh para calon pengguna.

Moderenisasi telah mempengaruhi semua sektor di sekitar kita termasuk pariwisata, hal tersebut merupakan implikasi dari jaman yang sudah biasa kita sebut millennial. Istilah Millennial di pariwisata atau millennial tourism dan digital tourism memang sangat erat kaitannya jika menghubungkannya dengan augmented reality. Augmented reality adalah sebuah konsep baru yang ditawarkan atas implikasi perubahan zaman di sektor pariwisata. Keseluruhan memang menawarkan satu hal penting dalam tujuannya yaitu memenuhi kenyamanan, kepuasan dan pengalaman baru. Kenyamanan telah dikonseptualisasikan sebagai pengalaman yang sudah ada di awal tahun 1970-an (Ritchie dan Hudson dalam Cavagnaro et al, 2018). Pengalaman pariwisata bagi para wisatawan terdiri dari tiga komponen utama yaitu kebutuhan untuk melakukan perjalanan dari origin ke destinasi, penyempurnaan dari pengalaman itu sendiri kemudian mengevaluasinya. Saat ini perubahan sudah sangat terasa, bagi pelaku bisnis pariwisata Indonesia dan dunia perlu segera mengantisipasi perubahan model bisnis pariwisata di era digital atau millennial tourism. Hal tersebut di sebabkan oleh pasar dunia yang akan mengalami perubahan dominasi oleh kelompok wisatawan generasi millennial yang memiliki usia rata-rata antara 16 tahun hingga 29 tahun atau yang lebih dikenal dengan generasi Y. Ketika menafsirkan pariwisata millennial sebagai trend-nya kaum muda, konseptualisasi pariwisata sebagai pengalaman bahkan lebih penting. Hal tersebut di karenakan para pelancong muda yang cenderung menolak produk standar atau homogen dan mencari solusi, ide, dan emosi baru atau, dalam satu kata, pengalaman baru. Pada akhirnya pariwisata millennial merupakan kegiatan wisata oleh para pemuda yang didefinisikan sebagai semua perjalanan independen untuk periode kurang dari satu tahun oleh orang berusia sangat produktif yang termotivasi, sebagian atau seluruhnya, oleh keinginan untuk merasakan budaya lain, membangun pengalaman hidup dan atau mendapat peluang manfaat dari pembelajaran formal dan informal di luar lingkungannya.

Industri pariwisata menjadi arena yang semakin kompetitif serta tujuan-tujuan pemasarannya telah menjadi tantangan yang wajib dihadapi oleh semua pihak yang memiliki kepentingan. Untuk mendapatkan keunggulan kompetitif, penggunaan teknologi modern sangat penting bagi banyak organisasi yang memiliki tujuan untuk memasarkan produknya secara lebih luas. Pengalaman virtual berbasis seluler untuk industri pariwisata telah diidentifikasi sebagai bentuk potensial untuk memodifikasi pra-perjalanan, dan pasca-konsumsi oleh konsumen saat ini (Kalawsky et al, dalam Schuemie et al, 2001). Meskipun augmented reality sebagai sebuah konsep telah ada sejak 1960-an, selama dua dekade terakhir menunjukkan bahwa kemajuan teknologi telah memungkinkan perumusan bidang penelitian yang maju dan berkembang. AR adalah teknik visualisasi yang menumpangkan data yang dihasilkan komputer, seperti teks, video, grafik, data GPS, dan format multimedia lainnya, di atas tampilan dunia nyata, yang diambil dari kamera komputer, ponsel, atau perangkat lainnya.

\section{B. HASIL PENELITIAN}

Augmented Reality (AR) adalah salah satu teknologi terbaru. Jika menoleh contoh dalam dunia telekomunikasi, teknologi tersebut menawarkan cara-cara baru secara efektif, inovatif dan menarik. Mengingat semakin populernya perangkat seluler dan antarmuka pengguna baru di seluruh dunia, 
penggunaan AR pada perangkat seluler berpotensi menjadi bentuk pendidikan sebagai sebuah pengalaman yang sangat penting. Augmented reality adalah beberapa cara untuk menampilkan konten dalam bentuk digital dalam gambar dunia nyata dan memungkinkan suatu interaksi pengguna dengan lingkungannya. Dalam mengatasi masalah, augmented reality memiliki perbedaan dengan apa yang disebut dengan realitas virtual. Augmented reality tidak memberi solusi pada masalah penglihatan para pengguna sehingga AR lebih berada pada posisi mempertahankan persepsi penuh terhadap realitas dunia, hanya saja dari segi pengalaman akan lebih ditingkatkan dengan bantuan lapisan digital yang dapat dibedakan dengan informasi melalui kecanggihan Teknologi Informasi Komputer (TIK). Dalam pendidikan sejarah dan pariwisata, penggunaan Augmented Reality ditujukan untuk penggunaan di luar ruangan dengan tingkat mobilitas pengguna yang tinggi. Untuk keperluan ini perlu suatu aplikasi yang memungkinkan penampilan Augmented Reality berjalan pada komputer, gadget dan perangkat teknologi visual dengan tingkat mobilitas tinggi beserta layanan data nirkabel. Ini berarti memerlukan gadget yang ringan, dimensi kecil dan konsumsi daya yang rendah serta baterai berkapasitas tinggi juga beberapa jam beroperasi tanpa perlu diisi ulang. Dengan kata lain, AR dapat menambah tampilan seseorang dan mengubahnya dengan bantuan komputer atau perangkat seluler, dan dengan demikian meningkatkan persepsi pengguna tentang kenyataan dan lingkungan sekitarnya. Selain itu, dalam konteks yang lebih tinggi teknologi AR menjadi lebih interaktif dan mudah "dimanipulasi" secara digital. Teknologi AR saat ini digunakan di sejumlah bidang antara lain, seperti kedokteran, pendidikan dan pelatihan simulasi. Teknologi AR Ini juga digunakan dalam sektor pariwisata, yang bertujuan untuk meningkatkan kualitas pengalaman wisata. Di satu sisi, beberapa contoh telah menunjukkan bahwa AR dapat membantu organisasi dan profesional pariwisata untuk menjangkau khalayak yang lebih luas dengan berfungsi sebagai teknologi pengiriman konten multimedia dan aplikasi seluler yang menarik, disesuaikan dengan berbagai tingkat pengetahuan dari para pengguna dan stakeholder. Sejumlah aplikasi telah dikembangkan berdasarkan kerangka kerja dan toolkit yang tersedia. Sementara banyak yang dimulai sebagai aplikasi percontohan atau proyek penelitian, beberapa di antaranya saat ini tersedia secara komersial. Namun yang paling penting, contoh-contohnya sangat beragam seperti pada tabel 1 .

Tabel 1. Cakupan aplikasi dan ketersediaan OS (Kounavis, Kasimati, \& Zamani, 2012)

\begin{tabular}{cccccc}
\hline AR & Place & iOS & Android OS & Symbian OS & BlackBerry OS \\
\hline Urban Sleuth & Urban & $\sqrt{ }$ & & & \\
Location & & & & \\
Tuscany+ & Tuscany & $\sqrt{ }$ & & & \\
Region & & & $\sqrt{ }$ & \\
Basel AR Tourist Guide & Basel & $\sqrt{ }$ & $\sqrt{ }$ & & \\
Street Museum & London & $\sqrt{ }$ & $\sqrt{ }$ & & \\
\hline
\end{tabular}

\section{Augmented Reality Sebagai Sebuah Trend}

Ketika berbicara tentang istilah millennial hal yang pertama muncul adalah kata "generasi". Hal tersebut merupakan gambaran dari subjek atau pemeran serta pelaku utama di dalamnya. Berkaitan dengan hal tersebut ialah generasi millenial disematkan pada wisatawan muda yang memiliki rentang usia antara 16 hingga 29 tahun. Mereka cenderung kreatif, cepat, spontan, tak terlalu banyak waktu untuk perencanaan, dan percaya pada ulasan-ulasan destinasi wisata di internet terutama pada media sosial. 
Maka tak heran kalau travel blogger maupun travel vlogger menjadi kiblatnya. Fenomena dari perilaku tersebut kemudian berkembang menjadi tren dan kian meluas. Berikutnya adalah perilaku dari pasar tersebut memiliki keunikan sebagai ciri khas mereka dan perlu dikenali lebih mendalam sebagai target segmen yang memerlukan perlakuan "khusus" terutama dari segi kebutuhan akan informasi yang lebih mudah, kelengkapan akomodasi, variasi bentuk produk dan layanan serta sudah barang tentu keterbukaan mengenai harga. Bagaimana mengenai potensi mereka? Di Indonesia melalui Kementerian Pariwisata (Kemenpar) RI menyadari bahwa wisatawan milenial memiliki potensi besar. Pernyataan tersebut sempat dilontarkan melalui Focus Group Discussion (FGD) di mana Kemenpar yang memprediksi peluang terhadap pengembangan produk wisata nasional, telah menyiapkan strategi untuk menjaring wisatawan millennial. Saat ini Kemenpar telah menempatkan program prioritas "Digital dan millennial" selanjutnya menjadi program strategis pertama di Kementerian tersebut (Sitio, 2018). Terdapat kaitan yang sangat erat antara digital dan millennial, karena potensi pengembangan yang besar dan sangat menjanjikan adalah disebabkan oleh digitalisasi pariwisata itu sendiri. Yang menjadi titik tolak perbedaan dengan sektor lain adalah penggunaan digital sebagai lifestyle. Masa depan menjadi lebih terbuka berkat akses informasi yang cepat, terbuka dan terdapat umpan balik yang simultan antara penyedia produk dan jasa dengan konsumennya (Noviyanti, 2014). Berdasarkan survei Everbrite-Harris Poll 2014, untuk mendapatkan pengalaman (experience) adalah prioritas para millennial tourist dalam motivasi wisatanya. Bagi mereka, hal itu lebih penting dibandingkan produk-produk tangible lainnya. Peluang tersebut tentu menjadi hal yang tak mau disia - siakan Kemenpar RI. Ditambahkan oleh Menpar bahwa terdapat kelompok millennial yang memiliki needs dan behavior khususnya bagi mereka yang tergantung dengan teknologi dan social media. Terdapat banyak aktivitas-aktivitas wisata yang telah beralih bentuknya dari bentuk terdahulu yang secara konvensional mengenal produk dan aktivitas wisata bersamaan saat mereka menginjakkan kaki di destinasi. Saat ini sudah berbeda, para tourist sudah mendapatkan hampir setengah dari keseluruhan informasi mengenai produk-produk wisata dan aktivitas yang ditawarkan di destinasi bahkan sebelum mereka tiba.

\section{Augmented Reality Sebagai Sebuah Value (Nilai)}

Penciptaan nilai telah banyak dibahas dalam literatur strategi bisnis dan umumnya dianggap sebagai kunci utama untuk pencapaian profitabilitas jangka panjang serta keberhasilan bisnis (Peppard \& Ward dalam Dieck \& Jung, 2017). Pada prinsipnya memberikan nilai tambah apalagi hal tersebut mempengaruhi kepuasan dan loyalitas pelanggan akan sangat mempengaruhi kesuksesan bisnis; dengan demikian penciptaan nilai dianggap sangat penting untuk segala bentuk operasional bisnis yang tentunya sangat menguntungkan (McDougall \& Levesque dalam Dieck \& Jung, 2017). Melville et al. dalam Dieck \& Jung (2017) mengusulkan model nilai bisnis berdasarkan Resource Based View (RBV) dan mengungkapkan bahwa organisasi harus memfokuskan strategi Teknologi Informasi mereka pada sumber daya internal dan yang tersedia daripada pada tren di pasar eksternal. Secara khusus, terungkap bahwa sumber daya tidak hanya harus dikaitkan dengan aset keuangan melainkan dengan keahlian, keterampilan dan pengalaman (Ward \& Daniel dalam Dieck \& Jung 2017). Nilai yang dirasakan tersebar di beberapa dimensi termasuk nilai ekologis, sosial, emosional, ekonomi dan fungsional. Menurut Fernandez dan Bonillo dalam Dieck \& Jung (2017), nilai epistemik atau predikat yang memiliki hubungan dengan pemenuhan keinginan akan pengetahuan, apakah ini dimotivasi oleh keingintahuan intelektual atau pencarian hal baru, ide tersebut terkait erat dengan mengintegrasikan AR ke dalam pengalaman. Seperti contoh pada atraksi yang bisa dicoba oleh pengelola museum untuk menciptakan cara interaktif baru dalam mengalami pengalaman akan sejarah dan tentu saja budaya (Kysela \& Štorková, 2015). Definisi holistik diberikan oleh Wu dan Liang dalam Dieck \& Jung (2017) yang mendefinisikan nilai pengalaman sebagai "nilai yang berasal dari bagaimana suatu produk mampu menciptakan pengalaman, 
perasaan, dan emosi yang tepat dalam diri seorang pelanggan". Temuan menunjukkan bahwa ada banyak dimensi nilai AR yang dirasakan dalam konteks pariwisata terutama warisan budaya untuk para pemangku kepentingan, termasuk nilai ekonomi, pengalaman, sosial, epistemik, historis \& budaya dan pendidikan (Dieck \& Jung, 2017).

Dari segi pengguna, kelas millennial yang diwakili oleh para wisatawan pengguna AR, cenderung resisten terhadap beberapa produk standar atau biasa dan selalu berupaya mencari solusi, ide, dan emosi baru atau dalam dua kata, pengalaman baru. Kelompok target millennial sebagai user yang sangat erat dengan teknologi augmented reality tidaklah homogen. Mereka datang dengan latar belakang yang berbeda baik dari segi sosial budaya origin, sosio-ekonomi, pendidikan, pengalaman, cara pandang dan karakter. Untuk memuaskan para wisatawan milenial saat ini dan masa depan, organisasi pariwisata harus mempertimbangkan nilai atau bahkan value for money yang lebih tinggi dari yang mereka miliki dan makna berbeda yang mereka berikan untuk bepergian. Mereka cenderung cepat merasakan kebosanan dalam aktivitasnya sehingga sangat memerlukan produk wisata yang sangat variatif dan terus up to date dalam siklus waktu yang relatif cepat. Hasil ini sebagian mirip dengan penelitian Kang \& Gretzel dalam Jung et al., (2016) yang menunjukkan hubungan yang kuat antara kehadiran dan pengalaman sosial (misalnya. Pengalaman kenikmatan dan melepaskan diri dari rutinitas yang membosankan yang berkaitan dengan kebebasan berekspresi). Selain itu, kecuali untuk pengalaman estetika, secara ekonomi juga AR memberikan pengalaman yang memiliki pengaruh signifikan terhadap para pengunjung, yang akibatnya mendorong niat wisatawan untuk mengunjungi kembali objek wisata. Khususnya, pengalaman hiburan ditemukan sebagai prediktor terkuat dari pengalaman wisata. Fenomena ini dapat dijelaskan dengan efek carry-over yang berarti bahwa kesenangan atau gairah yang timbul dari pengalaman awal berlanjut dalam pengalaman berikutnya (Menon \& Kahn dalam Jung et al, 2016). Dan pada akhirnya AR memainkan peran penting dalam meningkatkan kesadaran dan pengalaman sosial wisatawan serta pengetahuan sejarah dan geologis (Jung et al., 2016)

\section{Manfaat Augmented Reality untuk Wisatawan dan Pengalaman yang Ditawarkan}

Augmented reality telah terbukti sejauh ini sebagai teknologi yang dapat memberikan konten dan layanan yang jauh lebih personal yang disesuaikan dengan kebutuhan khusus wisatawan, dan tentu saja ini merupakan tantangan tersendiri bagi para pemandu wisata konvensional. Secara khusus, pemandu wisata AR dapat menampilkan konten berdasarkan permintaan saat wisatawan melakukan perjalanan di sekitar kota, menjelajahi lanskap kota dan situs. Format seperti itu, seperti yang sering dijelaskan, berkisar dari suara dan gambar kemudian dijadikan klip video, model 3D dan hyperlink yang dapat mengarahkan pengguna di luar aplikasi. Dengan demikian, dapat dikatakan bahwa aplikasi AR mobile memungkinkan pengguna untuk menjelajahi dunia dengan menambahkan layer baru ke realitas mereka, sehingga menghasilkan pengalaman baru, interaktif dan sangat dinamis (Kounavis et al., 2012). Ini menunjukkan bahwa aplikasi AR mobile dapat menawarkan nilai tambah lebih lanjut kepada wisatawan dengan memperkenalkan konsep konektivitas dan berbagi pengalaman. Selain itu, aplikasi AR seluler, sangat portable sehingga dapat berfungsi sebagai pemandu wisata "pribadi" yang selalu bisa memberikan informasi berdasarkan permintaan, sehingga di satu sisi dapat meminimalkan pengaruh informasi yang berlebihan serta pengaruh informasi yang tidak relevan. Salah satu implementasi AR di sektor pariwisata adalah mempromosikan dan menghadirkan objek wisata kepada wisatawan dalam objek tiga dimensi yang menarik dengan menggunakan ponsel pintar atau tablet. AR akan sangat berguna karena orangorang yang terlibat dalam bisnis pariwisata dapat menyajikan objek wisata secara virtual dalam 3D secara interaktif maupun secara real-time tentang objek yang mereka sajikan. Sistem informasi AR membantu wisatawan untuk mendapatkan informasi dan pengetahuan penting tentang objek wisata, sebanyak memberikan pengalaman baru, menghibur pengguna pada saat yang sama dan lebih bersifat kompetitif 
(Han., Jung, \& Gibson, 2012). Kita bisa melihat bagaimana kontribusi aplikasi yang diberi nama DewataAR dapat menampilkan objek tiga dimensi, video, dan informasi audio dari pura di Tanah Lot Tabanan, Bali. Hal tersebut merupakan momentum penting pengembangan aplikasi yang menyediakan sistem informasi tentang objek wisata dengan menerapkan teknologi augmented reality terutama tentang wisata alam berlatar budaya Bali. Dengan hanya memindai brosur objek wisata dengan menggunakan smartphone atau tablet Android, para wisatawan kemudian dapat menyaksikan objek tiga dimensi, video, bahkan informasi audio tentang objek wisata tersebut. Oleh karena itu, augmented reality dapat menjadi media alternatif untuk mempromosikan objek wisata yang menarik bagi wisatawan dan juga dapat mengembangkan pariwisata di Bali (Waruwu, et al, 2015)

\section{SIMPULAN}

Teknologi terbaru telah merevolusi cara orang merasakan lingkungannya. Batas yang dulunya begitu sulit ditembus berupa ruang, waktu, dan biaya terutama dalam melakukan perjalanan, kini telah bergeser dengan mudahnya. Semudah dengan hanya mengetuk layar ponsel, atau semudah menggeser jendela aplikasi di layar ponsel pintar. Perkembangan ini telah menyebabkan meningkatnya popularitas aplikasi AR untuk berperan penting dalam memproyeksikan informasi tambahan tentang atraksi, aksesibility dan amenity dalam lingkungan pariwisata menjadi lebih dekat bagi semua orang.

\section{DAFTAR PUSTAKA}

Cavagnaro, E., Staffieri, S., \& Postma, A. (2018). Understanding millennials' tourism experience: values and meaning to travel as a key for identifying target clusters for youth (sustainable) tourism. Journal of Tourism Futures, 4(1), 31-42. https://doi.org/10.1108/JTF-12-20170058

Han., D.-I., Jung, T., \& Gibson, A. (2012). Dublin AR: Implementing Augmented Reality (AR) in Tourism. Information and Communication Technologies in Tourism, 523, 511-523. https://doi.org/10.1007/978-3-7091-7596-5

Jung, T., Claudia, M., Lee, H., Chung, N., Jung, T., Claudia, M., ... Chung, N. (2016). Effects of Virtual Reality and Augmented Reality on Visitor Experiences in Museum Department of Food and. https://doi.org/10.1007/978-3-319-28231-2-45

Kounavis, C. D., Kasimati, A. E., \& Zamani, E. D. (2012). Enhancing the tourism experience through mobile augmented reality: Challenges and prospects. International Journal of Engineering Business Management, 4(1), 1-6. https://doi.org/10.5772/51644

Kysela, J., \& Štorková, P. (2015). Using Augmented Reality as a Medium for Teaching History and Tourism. Procedia - Social and Behavioral Sciences, 174, 926-931. https://doi.org/10.1016/j.sbspro.2015.01.713

SCHUEMIE, M. J., DER, S. P. VAN, MEREL, K., \& MAST, C. A. P. G. VAN DER. (2001). Research on Presence in Virtual Reality: A Survey. 4(2), 183-201. https://doi.org/10.1089/109493101300117884

Tom Dieck, M. C., \& Jung, T. H. (2017). Value of augmented reality at cultural heritage sites: A stakeholder approach. Journal of Destination Marketing and Management, 6(2), 110-117. https://doi.org/10.1016/j.jdmm.2017.03.002

Waruwu, A. F., Agung Bayupati, I. P., \& Gede Darma Putra, I. K. (2015). Augmented Reality Mobile Application of Balinese Hindu Temples: DewataAR. International Journal of Computer Network and Information Security, 7(2), 59-66. https://doi.org/10.5815/ijcnis.2015.02.07 